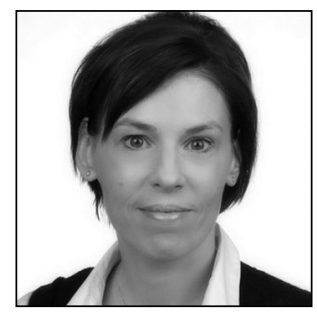

Mari Ann Simovart

\title{
Enforcement of Ineffectiveness of Unlawfully Modified Public Contracts
}

\section{Introduction}

Originating from the general principles of the EU public procurement law, the restrictions on modifying public contracts have been developed further by the EU legislator in the 2014 public and utilities procurement directives. ${ }^{{ }_{2}}$ The directives follow the rationale of the CJEU case law, ${ }^{*}$ prohibiting any substantial modification of public contracts, and introduce detailed criteria for distinguishing acceptable contract modifications from unacceptable (substantial) ones.

While the criterion of materiality as a measure of an amendment's lawfulness has received a good amount of attention in legal literature, ${ }^{*} 4$ equal attention has not been paid to wider legal implications and possible contradictions that can accompany the enforcement of these rules, particularly when the interaction with national legal systems of the EU is taken into account.

This work is supported by Estonian Research Council grant PUT639.

2 Directive 2014/23/EU of the European Parliament and of the Council of 26 February 2014 on the award of concession contracts, OJ L 94, 28/03/2014, pp. 1-64 (the Concessions Directive); Directive 2014/24/EU of the European Parliament and of the Council of 26 February 2014 on public procurement and repealing Directive 2004/18/EC; OJ L 94, 28/3/2014, pp. 65-242 (the Public Procurement Directive); Directive 2014/25/EU of the European Parliament and of the Council of 26 February 2014 on procurement by entities operating in the water, energy, transport and postal services sectors and repealing Directive 2004/17/EC OJ L 94, 28/3/2014, pp. 243-374 (the Utilities Directive).

3 Commission of the European Communities v. CAS Succhi di Frutta SpA, case C-469/99 P, ECLI:EU:C:2004:236; pressetext Nachrichtenagentur GmbH v. Republik Österreich (Bund), APA-OTS Originaltext-Service GmbH and APA Austria Presse Agentur registrierte Genossenschaft mit beschränkter Haftung, case C-454/06, ECLI:EU:C:2008:351; Wall AG v. La ville de Francfort-sur-le-Main and Frankfurter Entsorgungs- und Service (FES) GmbH, case C-91/08, ECLI:EU:C:2010:182.

4 A. Brown. When do changes to an existing public contract amount to the award of a new contract for the purpose of the EU procurement rules? Guidance at last in case C-454/06. - Public Procurement Law Review 6, 2008, pp. NA253-267; K. Hartlev, M.W. Liljenbøl. Changes to existing contracts under the EU public procurement rules and the drafting of review clauses to avoid the need for a new tender. - Public Procurement Law Review 2, 2013; S. Treumer. Regulation of contract changes leading to a duty to retender the contract: The European Commission's proposals of December 2011. - Public Procurement Law Review 5, 2012; S. Treumer. Contract changes and the duty to retender under the new EU public procurement Directive. - Public Procurement Law Review 3, 2014; M.A. Simovart. Lepinguvabaduse piirid riigihankes: Euroopa Liidu hankeõiguse mõju Eesti eraõigusele ['Limits to Freedom of Contract: the Influence of EC Public Procurement Law on Estonian Private Law'], doctoral thesis], 2010, available at https://dspace.utlib.ee/dspace/bitstream/handle/10062/15148/ simovart_mari_ann.pdf?sequence $=5$ (most recently accessed on 16.3.2016); M.A. Simovart. Amendments to procurement contracts: Estonian law in the light of the Pressetext ruling. - Juridica International 2010, No. 1, pp. 151-160, available at http://www.juridicainternational.eu/index.php?id=14581 (most recently accessed on 16.3.2016); Hankelepingu lubatud ja keelatud muudatused uute riigihankedirektiivide ülevõtmise järel ['Permitted and Prohibited Amendments After Transposition of the New Public Procurement Directives']. Juridica 2016/I, pp. 52-60. 
The primary remedy that interested parties can rely on when learning of a possibly unlawful modification is ineffectiveness of the public contract. ${ }^{*} 5$ However, because the contract performance phase is subject to the unharmonised private law of the Member States, enforcement of ineffectiveness as a result of unlawful contract modifications might be prone to specific fundamental difficulties. This article intends to 'map' such difficulties by looking at the access to the remedy of ineffectiveness in cases of unlawful public contract modification as well as the collateral implications following the ineffectiveness.

\section{Locus standi in claims of ineffectiveness due to unlawful public contract modification}

\subsection{The criteria for standing}

Any substantial modification of a public contract needs a new award procedure, ${ }^{*} 6$ the failure to conduct which can lead to ineffectiveness of the contract. Depending on the national law, ineffectiveness can be either retroactive cancellation of contractual obligations (ineffectiveness ex tunc) or cancellation of obligations that are still to be performed (ineffectiveness ex nunc) together with the application of other penalties. ${ }^{*} 7$ When a third party learns of a possibly unlawful modification of a public contract, it can submit a claim to either the court or another review body (as designated by the Member State) with the aim of establishing ineffectiveness of the contract.

For the purpose of creating an efficient review system, a relatively wide circle of third parties should have reasonable access to and be encouraged to make active use of the remedies available under the national review systems. ${ }^{*}$ The remedies directives oblige the Member States to make review procedures available to at least any and all concerned persons who fulfil the following two conditions: (i) the person must have or have had an interest in obtaining the concerned public contract and (ii) the person must have been or must risk being harmed by the alleged infringement. ${ }^{*} 9$

While the remedies directives do not seek to harmonise the national legislation completely with regard to locus standi, ${ }^{*} 10$ the national legislators are not free to give the established criteria any interpretation that could limit the effectiveness of the directive either. ${ }^{* 11}$ Thus, at minimum, review procedures in public procurement have to be available to parties who are interested in the concerned contract and are, or can be, harmed by the challenged breach.

The Member States may grant access to review more freely; however, the remedies system is not intended for availing stakeholders with indirect or general interest with the option to claim review of allegedly unlawful decisions or acts. For that purpose, the Member States can provide alternative options of review or allow for interests of the society to be considered or indirectly interested stakeholders to be involved otherwise. The possibility is mentioned in Recital 122 of the Public Procurement Directive (2014/24/EU) ${ }^{*}{ }^{12}$ : 'citi-

5 M.A. Simovart. Old remedies for new violations? The deficit of remedies for enforcing public contract modification rules. Upphandlingsrättslig Tidskrift 2015/1, available at http://urt.cc/sites/default/files/UrT\%202015-1_Simovert.pdf (most recently accessed on 14.3.2016), p. 35 .

6 Article 43 (5) of the Concessions Directive; Article 72 (5) of the Public Procurement Directive; Article 89 (5) of the Utilities Directive.

7 Article 2d (1) (a) and (2) of Council Directive 89/665/EEC of 21 December 1989 on the coordination of the laws, regulations and administrative provisions relating to the application of review procedures to the award of public supply and public works contracts, amended by Council Directive 92/50/EEC of 18 June 1992 L 209 and Directive 2007/66/EC of the European Parliament and of the Council; Article 2 d (1) (a) and (2) of Council Directive 92/13/EEC of 25 February 1992 coordinating the laws, regulations and administrative provisions relating to the application of Community rules on the procurement procedures of entities operating in the water, energy, transport and telecommunications sectors, amended by Council Directive 2006/97/EC of 20 November 2006 and Directive 2007/66/EC of the European Parliament and of the Council.

8 X. Zhang. Supplier review as a mechanism for securing compliance with government public procurement rules: A critical perspective. - Public Procurement Law Review 5, 2007, pp. 334-336, 340, 351.

9 Directive 89/665 and Directive 92/13, Article 1 (3), hereinafter: the remedies directives.

10 Case C-570/08, Symvoulio Apochetefseon Lefkosias v. Anatheoritiki Archi Prosforon, ECLI:EU:C:2010:621, para. 37.

11 Case 230/02, Grossmann Air Service, Bedarfsluftfahrtunternehmen GmbH \& Co. KG v. Republik Österreich. ECLI:EU:C:2004:93, para. 42.

12 Directive 2014/24/EU of the European Parliament and of the Council of 26 February 2014 on public procurement and repealing Directive 2004/18/EC, OJ L 94, 28/3/2014, pp. 65-242. 
zens, concerned stakeholders, [...] and other persons or bodies which do not have access to review procedures pursuant to Directive 89/665/EEC do nevertheless have a legitimate interest, as taxpayers, in sound procurement procedures. They should therefore be given a possibility, otherwise than through the review system pursuant to Directive 89/665/EEC and without it necessarily involving them being given standing before courts and tribunals, to indicate possible violations of this Directive to a competent authority or structure. So as not to duplicate existing authorities or structures, Member States should be able to provide for recourse to general monitoring authorities or structures, sectorial oversight bodies, municipal oversight authorities, competition authorities, the ombudsman or national auditing authorities.' In addition, Article 3 of Directive 89/665 provides for the Commission having a general power to intervene in matters where a serious infringement of EU law needs correction but has not been challenged. ${ }^{*}{ }^{*}$

In this light, questions arise with regard to cases like the recent UK decision in the matter of Winchester City Council ${ }^{* 14}$ where a councillor successfully applied for review of a decision by the City Council to modify a contract for the development of real estate without conducting a proper procurement for the modification. The applicant, Mr. Gottlieb, was neither an actual nor a potential bidder but instead a person clearly representing a general interest ('a resident, council tax payer, and City Councilor [...] seeking to ensure that the elected authority [...] complies with the law, spends public funds wisely, and secures through open competition the most appropriate development scheme for the City ${ }^{{ }^{*} 15}$ ). Despite that, he was found to have standing to challenge the City's decision to modify a contract with a developer, on the grounds that it breached the EU rules on public contract modification.

While it may be "uplifting" ${ }^{*} 16$ to see such a defender of indirect interests receive the standing and a doubtless just decision be awarded in the particular matter, the implications of giving standing overly generously in public contract cases in general can have a significant downside. Mainly, the risk of public contracts' validity being too easily challenged reduces legal certainty and counteracts the principle of pacta sunt servanda. Besides, fundamental differences in the national practice of allowing access to review could be argued to lead to lack of uniformity of the EU public procurement law with regard to remedies. Even though the CJEU has denied that national laws including contracting authorities within the class of persons to whom the review action is available would lead to a lack of uniformity in the application of the EU law, ${ }^{* 17}$ Recital 122 of Directive 2014/24/EU can be understood to indicate that the class of persons entitled to review should nevertheless not be extended to include persons protecting the general interests. The case of Winchester could therefore be treated rather as an exception justified by the accumulation of specific circumstances (the applicant being a council member, the subject matter of the contract pertaining to city planning and development - an area subject to very high public interest - etc.), as opposed to a routine example of finding standing in unlawful contract modification matters.

It is noteworthy that the rationale underlying government contract modification rules in the US is very close to the EU approach ${ }^{* 18}$ : any modification changing the purpose or nature of a contract so substantially that the original and the modified contract are materially different is subject to the statutory requirement for full and open competition ${ }^{*}{ }^{* 19}$ as provided under the Competition in Contracting Act (CICA). ${ }^{{ }^{2} 0}$ Not unlike

13 Case C-570/08, Symvoulio Apochetefseon Lefkosias v. Anatheoritiki Archi Prosforon, paras 26, 34.

14 R. Gottlieb (On the Application Of) v. Winchester City Council [2015] EWHC 231 (Admin); [2015] A.C.D. 74. See also R. Ashmore. Variations on a theme (Pressetext in action) / changes to development plans in favor of commercial developer successfully challenged: $R$ (on app. Gottlieb) $v$. Winchester City Council. - Public Procurement Law Review 3, 2015, NA81NA87; S.H. Bailey. Reflections on standing for judicial review in procurement cases. - Public Procurement Law Review 4, 2015, pp. 122-132.

15 R. Gottlieb (On the Application Of) v. Winchester City Council [2015] EWHC 231 (Admin), p. 151.

16 Ashmore, p. NA87, commending that decision as well as the overall modern liberal approach to standing in the public law of the UK; see Bailey, pp. 125, 129, 132.

17 Case C-570/08, Symvoulio Apochetefseon Lefkosias v. Anatheoritiki Archi Prosforon, paras 36-37.

18 See also C.R. Yukins. The European procurement directives and the Transatlantic Trade \& Investment Partnership (T-TIP): Advancing U.S. - European trade and cooperation in procurement (2014). GWU Law School Public Law Research Paper No. 2014-15; GWU Legal Studies Research Paper No. 204-15. Available at http://ssrn.com/abstract=2433219 or http://dx.doi. org/10.2139/ssrn.2433219 (most recently accessed on 15.3.2016), p. 15. There are some significant differences in the details of applying the general prohibition of material changes, though. E.g., while the US approach seems to favour broadly defined and general contracts for the purpose of accepting rather large-scale modifications, the EU's newly established contractmodification rules denounce overly wide discretion, standing clearly for specific and precisely drafted changes clauses. These differences do not, however, affect the suitability of comparing the practices with regard to standing requirements.

19 AT\&T Commc'ns, Inc. v. Wiltel, Inc., 1 F.3d 1201, 1204 (1993); CCL, Inc., 39 Fed. Cl. 180, 191-92 (1997).

2041 USCA $\S 3301$ (a). 
the EU law are also the basic criteria for establishing standing in procurement protests: actual or prospective bidders whose direct interest would be affected towards such award or failure are entitled to protest the decisions. ${ }^{* 21}$ The case law concerning unlawful contract modification in the USA's federal procurement has been accumulating already since 1880 . $^{{ }^{2} 2}$ Given the shared policy goals of the EU and US public procurement systems, the more 'experienced' case law of the US provides a valuable basis for comparison. A brief look at the US practice is therefore included in the following analysis.

\subsection{Sufficient interest in the modified public contract}

Mostly, procurement claims concern steps of the award procedure where the criterion of interest is satisfied when the person participates in the award procedure, even though a possibility or likelihood of winning the contract is not a required criterion for establishing standing. ${ }^{*} 23$ As a rule, it is difficult for a person who has not participated in the award procedure to demonstrate such an interest. ${ }^{* 4}$ The situation is different, however, in challenging of a contracting authority's decision to (not) advertise a contract ${ }^{*} 25$ - for instance, in the case of unlawful contract modification. In such cases, potential contractors must be entitled to bring a claim.

In the US, multiple fora for raising government-contract-related protests have developed historically: at present, parties are able to submit protests either to the United States Court of Federal Claims or to the Government Accountability Office (GAO). ${ }^{*} 26$ The extensive case law accumulated by the GAO as the main venue for protest action generally follows the line of reasoning that a party does not have a sufficient interest when said party would not be ineligible to compete for the contract if the protest were resolved in its favour. ${ }^{*} 7$ Parties who could not act as bidders even potentially are not considered to be interested parties in procurement protests in general, ${ }^{* 28}$ and not in contract modification cases in particular. ${ }^{* 29}$ Under the same rationale, subcontractors are refused standing in contract modification protests, ${ }^{*} 30$ even though individual exceptions to that understanding have been mentioned. ${ }^{*}{ }^{31}$ As a rule, for purposes of a protest alleging that changes to a government contract are so substantial that the contract should be terminated and a new

31 U.S.C. $\$ 3551(2), 4$ C.F.R. $§ 21.0(a)(1)$.

22 C.D. Swan. Lessons from across the pond: Comparable approaches to balancing contractual efficiency and accountability in the U.S. bid protest and European procurement review systems. - Public Contract Law Journal 43.1 (Fall 2013), p. 35.

23 D. Pachnou. The Effectiveness of Bidder Remedies for Enforcing the EC Public Procurement Rules: A Case Study of the Public Works Sector in the United Kingdom and Greece. University of Nottingham 2003, p. 106.

24 Dischendorfer. Challenging discriminatory technical specifications under the Remedies Directives: The Grossmann case. P.P.L.R. 2004, 4, NA98-102, p. NA102.

25 S. Arrowsmith. The Law of Public and Utilities Procurement, 2005, para. 21.6; R. Caranta. Damages for breaches of EU public procurement law: Issues of causation and recoverable losses. - D. Fairgrieve, F. Lichere, editors. Public Procurement Law: Damages As an Effective Remedy. Oxford and Portland, Oregon, 2011, pp. 167-168.

26 On controversies in applying the standing rules in government contract disputes, see B.M. Byrd. Contractors stand strong: Those 'adversely affected or aggrieved by agency action' should have standing to expose government procurement regulation violations to mitigate waste in contingency contracting. - Federal Circuit Bar Journal 22, 2013, passim; F.W. Claybrook, Jr. Standing, prejudice, and prejudging in bid protest cases. - Public Contract Law Journal 33, Spring 2004, passim; F.W. Claybrook, Jr. Please check your crystal ball at the courtroom door - a call for the judiciary in bid protest actions to let agencies do their job. - Public Contract Law Journal 38, Winter 2009, passim; W. N. Keyes. Government Contracts under the Federal Acquisition Regulation. Thomson West 2003, pp. 736, 738, 761; P.H. Polling. The Federal Circuit's folly: Misconstruing government contractor standing rules in the Court of Federal Claims. - Public Contract Law Journal 36, Fall 2006, passim.

27 R. Prevost. Contract modification vs. new procurement: An analysis of General Accounting Office decisions. - Public Contract Law Journal, 15.71985, p. 454.

28 There have been exceptions to that rule. E.g., a proposed or possible subcontractor can be an interested party 'where no other immediate party had a greater interest concerning the issue raised and where there was a possibility that the subcontractor's interest would be inadequately protested if our bid protest forum were restricted solely to potential awardees' (California Microwave, Inc., 54 Comp. Gen. 231 (1974), 74-2 CPD 181; Abbott Power Corporation, B-186568, December 21, 1976, 76-2 CPD 509). Also, 'a subcontractor whose product was mentioned by name in the specifications was sufficiently interested to protest the solicitation's "brand name or equal” provisions' (Mosler Systems Division, American Standard Company, B-204316, March 23, 1982, 82-1 CPD 273). An electrician-subcontractor was considered to have a standing to challenge 'the wage rates for electricians set forth in the solicitation' (Rosendin Electric, Inc., 60 Comp. Gen. 271 (1981), 81-1 CPD 119 (most recently accessed on 9.3.2016)).

29 Prevost 1985, p. 455.

30 International Genomics Consortium v. the United States, 104 Fed. Cl. 669 (2012), 669, 674.

31 Keyes 2003, p. 746; Prevost 1985, pp. 455, 462. 
competition conducted, only a party who can participate as a potential offeror has a direct and established interest in the opportunity to compete for the award. ${ }^{*}{ }^{32}$

The case of Onix Networking Corporation ${ }^{*} 33$ provides an example: The Peace Corps solicited a contract to renew its existing software licences for Microsoft products and to acquire technical services, limiting the original competition to authorised Microsoft resellers only and awarding the contract to En Pointe, a reseller of Microsoft products and services. Later, the Peace Corps decided to acquire 'cloud-based' e-mail as a service (EaaS) as opposed to its existing e-mail functionality and for that purpose conducted a pilot programme to test both Microsoft and Google EaaS products. Even though the test users praised both products as appealing, the Microsoft EaaS product was ordered from En Pointe via a contract modification eventually. The modification was protested by Onix, an authorised reseller of Google products, and ruled to be improper by the GAO. ${ }^{*} 34$ Even though the Peace Corps claimed Onix not to be an interested party, as it could not meet the requirements set for the modification, the GAO found otherwise. Because the contracting agency had never issued any actual definitive requirements as to delivering the desired product, there was no basis for finding the protestor incapable of meeting the (non-existent) requirements and no reason to not consider them to be an interested party, inter alia, the GAO took into account that some of the desired features as referred to by the agency were allegedly restrictive of competition and if officially stated in a competition would be challenged by the protestor. ${ }^{*}{ }^{35}$

In some cases pertaining to public contract modifications, it has been argued that the circle of interested parties should be limited to the participants in the initial tender, when there was one. The reason this argument is not justified relies firstly on the very logic prohibiting substantial contract changes. As established in the landmark case Pressetext as well as the 2014 directives, it is, namely, the hypothetical implication of the amendment for the results of the original award procedure that serves as a criterion for finding an amendment unacceptable. Had the change been made to the terms of the initial award procedure, the contract might have attracted different bidders or could have been awarded to a different entity. The party disputing the amendment can very well belong to the group of such potentially attracted different bidders. Secondly, the initial procedure may have taken place a relatively long time ago, in which case there might not be a real correlation between any previous and present interests. Thirdly, should a modification truly appear to be a significant one, it creates a de facto new contract that has actually never been subject to an award procedure at all. Such situations must be regarded as not unlike other cases of failure to advertise and must allow any potential contractors to challenge the unlawful decision, without the need to show actual participation in the initial contract award procedure.

This conclusion is supported by the US case law as well. For instance, in a case of a government contract for the lease and the recycling of acrylic plastic media, awarded by the Department of the Air Force, PolyPacific Technologies, Inc., the protester, did not submit a proposal in the original competition because it was not on the list of qualified providers of the required type of plastic media at the time when proposals were due. However, it later became approved as a qualified provider. In a protest concerning contract modification, Poly-Pacific were found to be a prospective offeror with direct economic interest affected by the failure to award the contract properly. ${ }^{*}{ }^{6}$ The mere fact that the protester could not or did not participate in the award procedure preceding the initial contract award does not take away its chances of challenging unlawful amendment of that contract. ${ }^{*} 3$

32 E.g., Memorex Corporation, B-200722, Oct. 23, 1981, 61 Comp.Gen. 42, pp. 1, 4.

33 Onix Networking Corporation, B-411841, Nov. 9, 2015, http://gao.gov/assets/680/673620.pdf (most recently accessed on 7.2.2016).

34 The ruling pointed to 'a fundamental flaw in the agency's logic': while the original competition had been limited to Microsoft resellers only, indicating that only Microsoft products would meet the agency's requirements, subsequent actions such as the pilot programme 'explicitly recognize that there are firms other than Microsoft authorized resellers, and products other than Microsoft's EaaS product, that are available to meet the agency's requirement'. Furthermore, the original competition never contemplated the acquisition of cloud-based EaaS or of any other entirely new product or service but was, on the contrary, limited to a specific list of products and services. Onix Networking Corporation, B-411841, pp. 1-3, 6-9.

35 Onix Networking Corporation, B-411841, pp. 4-5 (most recently accessed on 7.2.2016).

36 Poly-Pacific Technologies, Inc., B-296029, June 1, 2015, http://gao.gov/assets/380/374466.pdf, p. 2 (most recently accessed on 8.2.2016).

37 Ibid., p. 2; see also Memorex Corporation, B-200722, p. 4. 


\subsection{Prejudice caused by the unlawful modification}

Prejudice, or suffering of harm through the challenged breach, is an essential element of standing in the US. ${ }^{*}{ }^{8}$ However, there is some controversy with regard to establishing the prejudice as a part of the protestor's standing. ${ }^{*} 39$

On the one hand, cases like Myers suggest a protestor must show that it would be a qualified bidder, regarding the mere fact that it might have submitted a bid as insufficient. ${ }^{*} 40$ On the other hand, judgements like the one in the above-referred-to Poly-Pacific regard the loss of a chance to participate in a competition for a federal contract as sufficient to find the protester prejudiced by the improper modification. ${ }^{* 41}$ Similarly, in the case of Distributed Solutions, Inc., the Court established that the plaintiffs suffered a loss of an opportunity to compete fully and fairly for a federal procurement opportunity and therefore suffered a 'non-trivial competitive injury sufficient to satisfy the jurisdictional standing requirement. ${ }^{*}{ }^{42}$ (Even more confusingly, some GAO rulings point out that the protestor, in order to show the prejudice, must show how the challenged modification would have influenced the original competition. ${ }^{*} 43$ This approach cannot be justified. While it is right to compare the original and the modified contracts in order to establish whether the modification is a substantial one, there is no reason to compare the chances of the protestor in the actual and hypothetical past competitions for the purpose of establishing the suffering of loss through a contract modification.)

The protests based on unlawful contract modification are aimed at opening a new competition, the exact terms of which are unknown at the time of the dispute. It's therefore the chance of bidding in such hypothetical competition that should be looked at when establishing the presence of a prejudice. A protestor should be able to show that it could reasonably be awarded the new contract and is suffering from harm by way of missing that chance. The protestor does not have to convince the court that it would have been awarded the contract had the procedure been lawfully undertaken. ${ }^{*} 44$

Not unlike the US requirement of prejudice, the EU remedies directives allow the Member States to make the review procedures subject to the claimant being or risking being harmed by the alleged infringement. ${ }^{*} 4$ The CJEU has never actually had a chance to articulate its position on this issue. The question of establishing 'harm' was posed to the CJEU in the Pressetext case: 'Is "harmed" in Article 1 (3) of Directive 89/665 [...] and in Article 2 (1) (c) of that directive to be interpreted as meaning that an undertaking [...] is harmed [...] simply where he has been deprived of the opportunity to participate in a procurement procedure because the contracting authority did not, prior to making the award, publish a contract notice, on the basis of which the undertaking could have tendered for the contract to be awarded, could have submitted an offer or could have had the claim that exclusive rights were involved reviewed by the competent procurement review body?'. The question was presented conditionally, depending on the court's answer to the first questions, and in light of these, the Court did not have to answer it. ${ }^{*} 6$

However, the opinion of Advocate General Kokott in the case of Pressetext offers a good insight into the matter of establishing harm as a part of the locus standi test. It suggests that application of the standards of locus standi and restriction of access to review options must 'not affect the practical effectiveness of the directive. ${ }^{*} 7 \mathrm{~T}$ Therefore, the right to bring an action in procurement review proceedings may not be restricted

38 Myers Investigative and Security Services, Inc. v. United States, 275 F.3d 1366 (2002), 1366.

39 See Byrd 2013, passim; Claybrook 2004, passim; Claybrook 2009, passim.

40 Myers Investigative and Security Services, Inc. v. United States, 1366.

41 Poly-Pacific Technologies, Inc., B-296029, p. 6.

42 Distributed Solutions, Inc., and STR, L.L.C. v. the United States, 104 Fed. Cl. 368 (2012), 368, 377, 380. See also Weeks Marine, Inc. v. United States, 575 F.3d 1352, 1362 (Fed. Cir. 2009).

43 E.g.: Armed Forces Hospitality, LLC, B-298978.2, B-298978.3, Oct. 1, 2009, http://gao.gov/assets/390/386896.pdf, pp. 9-10; Emergent BioSolutions Inc., B-402576, June 8, 2010, http://gao.gov/assets/390/389187.pdf, p. 14 (most recently accessed on 16.3.2016).

44 Claybrook 2009, pp. 384, 386, 389.

45 Case 249/01, Werner Hackermüller v. Bundesimmobiliengesellschaft mbH (BIG) and Wiener Entwicklungsgesellschaft mbH für den Donauraum AG (WED), ECLI:EU:C:2003:359, para. 19.

46 Pressetext, paras 27, 89.

47 The Opinion of Advocate General Kokott delivered on 13 March 2008. Case C-454/06, Pressetext Nachrichtenagentur GmbH v. Republik Österreich (Bund), APA-OTS Originaltext-Service GmbH and APA Austria Presse Agentur registrierte Genossenschaft mit beschränkter Haftung. ECLI:EU:C:2008:167, para. 144; reference to the following: Case C-410/01, Fritsch, Chiari \& Partner and Others, paras 31, 34; Case C-470/99, Universale-Bau, para. 72; and Case C-230/02, Grossmann Air Service, para. 42. 
disproportionately. With regard to the standard of 'harm', asserting that there is a possibility of the occurrence of damage must be sufficient. Furthermore, the possibility of harm 'must be presumed where it is not manifestly excluded that the applicant would have received the award if the legal infringement alleged had not occurred'. ${ }^{*} 48$ This way, the requirement of harm is applied so as to open review procedures to a wider rather than a smaller circle of interested parties, ${ }^{*} 49$ as the essence of the review system demands.

Decisions on contract modification should be open to review on flexible grounds, rejecting as inadmissible $a b$ initio by reference to a lack of standing only the cases where the lack of standing is so plainly obvious as to require no further examination. ${ }^{*}{ }^{50}$ An example of a 'plainly obvious' impossibility of competing would be present in the case of a company that conducts business in an area different from that expected under the concerned contract (a shoemaking factory challenging a construction contract). Also, any person who would be excluded from the procurement under the mandatory clauses of exclusion ${ }^{*}{ }^{51}$ (e.g., due to participation in terrorist offences, money-laundering, child labour, etc.) shouldn't have standing, perhaps with possible exceptions where they demonstrate reasonable grounds for applying the self-cleaning exception ${ }^{*}{ }^{2}$ or an exception for overriding reasons related to the public interest ${ }^{*} 53$.

In conclusion, in cases of illegal direct contracting, both the party's interest towards the modified contract and suffering of loss must be considered to be present whenever the company could be able to bid in the hypothetical award procedure that should be conducted instead of modification of the concerned contract. Only when it is 'plainly obvious' that the person is not capable of competing for the contract should they have no standing. Otherwise, overly restricted access to the proceedings would render any effective review excessively difficult, possibly limiting the effective enforcement of the directive and counteracting the purposes of the whole remedies system.

\section{Indirect implications of public contract ineffectiveness}

\subsection{Scope of ineffectiveness}

While the basic essence of ineffectiveness is well defined as exclusion of the continued legal force of a public contract, the directives leave some room for different interpretations regarding the scope of the impact of ineffectiveness. Namely, it is not clear whether the resulting ineffectiveness must concern the whole modified contract or can apply to the unlawful amendment only. Both possibilities can be deduced from the language in the famous case Pressetext ${ }^{*} 54$ where the Court describes substantial amendments as renegotiations of the initial contract as well as de facto new awards. Here, the references to the use of negotiated procedure without publication seem to support the understanding that a new award of additional or repeated services, if necessary, can be isolated from the rest of the contract (e.g., para. 36). On the other hand, description of an amendment as renegotiation of the initial contract looks at the modified contract as a whole (e.g., para. 34).

Similarly, both the duty to retender the initial (renegotiated) contract and the obligation to conduct a new tender for the amendment have been referred to in the literature. ${ }^{*} 55$ S.T. Poulsen has openly acknowledged that a new tendering procedure can be necessary either for a whole new contract or for a supplementary contract dealing with the amendment. ${ }^{* 6}$ That approach seems to correspond to the traditional

48 The Opinion of Advocate General Kokott, Case C-454/06, para. 148.

49 Case 249/01, Hackermüller, paras 22, 24-29. Also Case 100/12, Fastweb SpA v. Azienda Sanitaria Locale di Alessandria. ECLI:EU:C:2013:448, paras 26-29.

50 The Opinion of Advocate General Kokott, Case C-454/06, paras 146-150.

51 The Concessions Directive, Article 38; the Public Procurement Directive, Article 56; the Utilities Directive, Article 80.

52 The Concessions Directive, Article 38 (9); the Public Procurement Directive, Article 56, Section 6; the Utilities Directive, Article 80.

53 The Concessions Directive, Article 38 (6) the Public Procurement Directive, Article 56, Section 3; the Utilities Directive, Article 80.

54 Pressetext Nachrichtenagentur GmbH v. Republik Österreich (Bund), APA-OTS Originaltext-Service GmbH and APA Austria Presse Agentur registrierte Genossenschaft mit beschränkter Haftung. ECLI:EU:C:2008:351.

55 Most references have been made to the duty to retender the modified contract (i.e., the whole contract as opposed to just the modified part of it) - e.g., K. Hartlev, M.W. Liljenbøl 2013, pp. 51, 54; Treumer 2012, pp. 154, 155, 165; Treumer 2014, p. 148. However, the requirement of a new tender for additional works only is mentioned in Treumer, 2014, p. 150.

56 S.T. Poulsen. The possibilities of amending a public contract without a new competitive tendering procedure under EU law. - Public Procurement Law Review 5, 2012, pp. 167-187 (on pp. 167, 168, 170). 
civil-law rule: when a part of a contract appears to be illegal, the rest of the contract can continue to be in force if the illegal part is separable from the rest, unless entry into the contract was conditional on the illegal part to begin with. ${ }^{*} 57$ By the same rationale, an unlawfully modified public contract can remain in force without the modified part when the modification can be separated out - presuming that making the modification was not a precondition for entering into the public contract.

Among the cases of substantial modifications listed in the directives, additional works (supplies and services) that overstep the limits provided in Section 1 (b) could perhaps be examples of separable modifications. The same could apply to modifications that considerably extend the scope of a contract (Section 4 (c)), particularly extensions in time - an additional contract period for services, for example. On the other hand, an unlawful change of contracting partner could serve as an example of change that probably cannot be separated from the rest of the contract, unless the substitution is clearly intended for a part of the contract only.

Any specific difficulties seem largely attributable to cases where the whole contract should have been put out for a new tender, as opposed to modifications separable from the initial contract that do not influence the validity of the initial contract and thus provide no particular difficulties in comparison to random cases of contract ineffectiveness.

\subsection{Negative influence on contractors (suppliers)}

For obvious reasons, a breach of contract-modification rules always occurs within a framework of valid contractual relations and may possibly happen in an advanced stage of contract performance. In a situation where the contractor (service provider) has already devoted significant efforts and costs to preparing and in anticipation of the performance, as well as in the course of actual performance, public contract ineffectiveness can subject the contractor to major negative consequences financially. ${ }^{*} 8$

This can be particularly true when the contract terms provide for no payments by the contracting authority until the last phases of delivery, demand expensive warranties from the contractor, or make the contractor enter into costly agreements with subcontractors or suppliers which agreements ineffectiveness renders it unable to fulfil. Moreover, in the outcome, ineffectiveness can have especially serious consequences with regard to arrangements of financing. ${ }^{*}{ }^{9}$ Although all of that can also apply in cases of ineffective initial contracting, the difference lies, firstly, in the fact that an unlawfully modified contract started out as a perfectly legitimate contractual relationship. Secondly, while the term for claiming ineffectiveness of an illegally awarded contract starts to run from the beginning of the contract period, the same term for an illegal modification proceeds from the moment of making the illegal amendment, which itself can follow an already extensive contract period. In comparison, the implication of ineffectiveness of modified contracts therefore carries the possibility of somewhat more complications.

In addition to immediate financial implications, agreeing to an unlawful public contract modification may subject the contractor to collateral consequences in future procurements. Namely, under the new directives, contracting bodies will be entitled or - depending on the Member State's law - even obliged to exclude a tenderer from an award procedure if the latter 'has shown significant [...] deficiencies in the performance of a substantive requirement under a prior public contract [...] which led to early termination of that prior contract, damages or other comparable sanctions' ${ }^{* 60}$ It is not clear whether unlawful modifications of public contracts can be regarded as such significant deficiencies in the performance of a substantive requirement under a public contract.

The answer may be positive when one considers the contract-modification rules to be an implicit part of the contract, or if the public contract incorporates the rules on modification by reference or expressly lists

57 See also K. Struckmann, P. Hodal. Private enforcement of contract ineffectiveness: A practitioner's point of view. - European Procurement \& Public Private Partnership Law Review 9, 2014, p. 32.

58 A decision of ineffectiveness can cause 'considerable upset and financial losses' to all parties concerned, including the successful tenderer - Case C-166/14, MedEval - Qualitäts-, Leistungs- und Struktur-Evaluierung im Gesundheitswesen GmbH. ECLI:EU:C:2015:779, p. 40.

59 Struckmann, Hodal 2014, pp. 32-33.

60 Article 38 (7) (f) of the Concessions Directive; Article 57 (4) (g) of the Public Procurement Directive. The Utilities Directive refers to the possibility of using the same grounds established under the Public Procurement Directive - Utilities Directive, Article 80 (1). 
the same rules. In the latter case, the breach of modification rules really would equate to a 'deficiency in the performance'. It also clearly leads to sanctions comparable to those for early termination, as the directive requires as the second precondition for exclusion.

The recitals of the directive explain the necessity for such a clause, referring, inter alia, to the contracting authority's need to 'be able to exclude candidates or tenderers whose performance in earlier public contracts has shown [...] misbehavior that casts serious doubts as to the reliability of the economic operator'. Can participation in a prior unacceptable contract modification cast serious doubts on the contractor's reliability? The language of the recitals can well be interpreted to support that conclusion and to allow exclusion of any tenderer for having participated in a prior unlawful contract modification.

The above examples seem to indicate that, as a result of unlawful contract modification, the remedy of ineffectiveness can de facto seriously penalise the concerned contractors (suppliers and service providers). ${ }^{* 61}$ In this regard, the influence of the contract-modification rules and the remedy of ineffectiveness can be said to be fundamentally distinct from the rationale of the rest of the EU public procurement law. While, generally, following EU public procurement rules is understood to be mandatory for the contracting authorities as addressees of the legislation, here, the suppliers (contractors) can be subjected to significant costs, deprived of the expected profit, and perhaps excluded from future procurements as a result of breach of EU public procurement rules. Notably, such consequences depend largely on the choices of national legislators, possibly reducing the uniformity of EU public procurement law.

A question may be asked as to whether the result of de facto penalising suppliers for a breach of public contract modification rules is in harmony with the purpose and the general principles of the public procurement law. On one hand, the birth of the concept of ineffectiveness itself seems to lead to the conclusion that, next to contracting authorities, suppliers bear part of the responsibility for following EU public procurement law. For instance, in the case Commission v. Germany (C-503/04), the Court refused to uphold the arguments of the participating Member States in protection of the continued effect of the wrongfully awarded contract with reference to, inter alia, the principles of legal certainty and the protection of legitimate expectations. ${ }^{*}{ }^{62}$ Disregarding possible legitimate expectations of the other contracting party or any 'provisions, practices or situations prevailing' in Member States' domestic legal order, the Court asserted that no private-law interest could 'justify the failure to observe obligations arising under Community law'. 63 Therefore, contracting parties cannot be exempted from suffering the consequences of being a party to an illegal award, even if the party subject to the regulation and therefore technically the only one in breach is actually the contracting authority.

A similar example of rationale submitting otherwise 'innocent' parties to regulation not directly addressed to them can be found in the CJEU case law with regard to the state-aid law. Here, an undertaking is presumed to have a duty of diligence to determine whether the required procedure for granting aid has been followed. By analogy, suppliers (contractors) under public contracts can be subjected to a certain duty of diligence to know and to follow the main rules of EU public procurement law, incl. the fundamental rules on contract modification. ${ }^{*} 64$

On the other hand, the Court in Pressetext acknowledged the possibility of the contractor having a rightful claim of damages against the contracting authority under the domestic law (para. 36). Such acknowledgement indicates the opposite - any negative consequences can be compensated for and made good later, confirming the status of suppliers as innocent bystanders.

61 See, on this subject, J. Arnould. Damages for performing an illegal contract: The other side of the mirror - comments on the three recent judgments of the French Council of State. - Public Procurement Law Review 6, 2008, p. NA275: 'the nullity of the contract [...] makes another "victim" of the infringement of the public procurement rules: the supplier, service provider or contractor with which the contract was concluded.'

62 Case C-503/04, Commission of the European Communities v. Federal Republic of Germany, ECLI:EU:C:2007:432, para. 31.

63 Paras 32, 33, 38.

64 M.A. Simovart. Limits to freedom of contract... 2010, pp. 201-202. On the matter of contractors' diligence in public contracting situation, see also K.-M. Halonen. Hankintasopimuksen tehottomuus: hankinta- ja velvoiteoikeudekkinen tutkimus hankintasopimuksen tehottomuudesta ja hankintayksikön vahingonkorvausvastuusta sen entiselle sopimuskumppanille. Turku: Turun yliopisto 2015, pp. 191-200; K.-M. Halonen. Shielding against damages for ineffectiveness: The limitations of liability available for contracting authorities - a Finnish approach. - Public Procurement Law Review 4, 2015, pp. $115-117$. 


\subsection{Damage claims of contractors (suppliers) based on contract ineffectiveness}

Following the declaration of ineffectiveness of a partially performed modified contract and having suffered financial harm as a result, the former contracting partner may resort to claiming damages or restitution from the contracting authority as the party generally regarded as liable for following the EU procurement rules. ${ }^{* 65}$

Such claims are subject to unharmonised private-law rules of the Member States and can lead to controversial results and significant legal uncertainty. ${ }^{* 6}$ Under some legal regimes, ex-contractors may be awarded generous compensation as a result of contract ineffectiveness, while the situation may be the opposite and successful claims of damages very problematic in other jurisdictions - often because of hardship related to the required burden of proof. ${ }^{*} 67$ When the contract has been declared ineffective $e x$ tunc, or void, the contract's clauses cease to carry any legal force. In such a situation, most civil-law jurisdictions prescribe restitution and return of receivables under unjustified enrichment law. ${ }^{* 68}$ These rules prescribe the return of, or compensation for, everything received under the void contract and may even oblige the contractor to pay interest on the sums received for performance in advance (if any).

With a view to possible differences in national approaches, J. Arnould has referred to the need for the EU law to find solutions to conflicting rules on compensating for damages. ${ }^{* 69}$ National rules on unjustified enrichment and/or damage claims that are overly restrictive towards ex-contractors' claims against contracting authorities, and demand too high a level of diligence from contractors, may inhibit fair competition in public procurement. Accordingly, the law would not be in harmony with the rationale of the EU public procurement law. On the contrary, regulations unreasonably generous to ex-contractors under ineffective public contracts tend to eliminate the economic operators' incentive to ensure a modification's lawfulness, and can undermine the remedy's efficacy. ${ }^{*} 70$

At present, acknowledgement of such considerations and the drawing of a reasonable balance are left solely to the national legislators. However, application of EU public procurement law would benefit from a levelled approach to the rights ex-contractors have in cases of ineffectiveness following unlawful contract modifications. When the extent of reimbursement allowed for contractors in such cases differs significantly from Member State to Member State, the enforcement of the new public contract modification rules leads to significant divergence in the EU-wide legal situation and might work against the actual purpose of establishing the common rules on contract modification.

\section{Access to information as a prerequisite to review"}

Under the peer-review (supplier-initiated) remedies system, any genuine opportunity for timely challenge of a contracting authority's failure to follow the rules on public contract modification presumes the competitors' knowledge of the making of a modification. The lack of publicly available or disclosed information about amendments creates an obstacle to submitting claims of unlawful contract modifications. ${ }^{*} 72$

At present, the (mostly) private-law contracts awarded in public procurement can be subject to unfounded confidentiality agreements. Typically, competitors do not have any information about a

65 Struckmann, Hodal 2013, p. 34; Halonen. Shielding against damages... 2015, p. 112.

66 On the subject of damages as a remedy in different Member States generally, see, e.g., D. Fairgrieve, F. Lichere, editors. Public Procurement Law: Damages as an Effective Remedy. Oxford and Portland, Oregon, 2011.

67 E. Fels. Euroopa Liidu riigihankeõiguse normide rikkumise mõju hankelepingu kehtivusele. Magistritöö. Juhendaja: M.A. Simovart ['Contract validity in the case of infringement of European Union public procurement rules', a master's thesis; supervisor: M.A. Simovart]. Tallinn, 2015, p. 56; Halonen. Shielding against damages... 2015, pp. 112-113.

68 Struckmann, Hodal 2014, p. 35.

69 Arnould, p. NA275.

70 Arnould, p. NA278.

71 See, on this subject, Ginter, Parrest, Simovart. Access to the content of public procurement contracts: The case for a general EU-law duty of disclosure. - Public Procurement Law Review 4, 2013, pp. 154-164; Ginter, Parrest, Simovart. Ärisaladuse kaitse ja hankelepingute avalikustamise nõue riigihankeõiguses. Juridica 2013, No. 9, pp. 658-665.

72 M.A. Simovart. Old remedies for new violations? UrT 2015/1, p. 45. The difficulty of bringing a timely action of ineffectiveness when there has been no prior publication of contract notice has been recognised in Case C-166/14, MedEval, para. 42. 
modification being made, or about its content, and are thus not aware of any possibly occurring breach. ${ }^{*} 73$ In effect, substantial modifications may easily go unchallenged and remain in force for the mere reason of lack of information about them.

Even though a default requirement of disclosure about public contracts and their modifications can be argued to follow from the EU procurement law's general principle of transparency, a duty to provide access to public contracts is not yet a clearly established or universally followed rule in all Member States. An explicit default right of access to information about the performance stage of public contracts would facilitate actual information about contract modifications. Under the new directives, some contract modifications are subject to reporting by contracting authorities and entities, ${ }^{*} 74$ but these obligations do not apply to all cases of modifications.

The default disclosure rule has, inter alia, been recommended with the purpose of improving anticorruption policies in public procurement ${ }^{*} 75$ as implementing high transparency standards and strengthening control mechanisms during the contract performance period. Establishing reasonable restrictions on drafting and enforcing confidentiality clauses in public procurement contracts under the national laws is therefore advisable.

In addition to the lack of information, procedural issues and lack of motivation may lessen third-party initiative to review contract modifications. Breaches of contract modification rules have been described as falling into the category of cases that do not benefit from the advantages normally applicable to the supplier review system: the competitors are not able to monitor the making of the modifications and to detect breaches in a timely manner, the process of contract performance is not closely related to the competitors' direct interests, and the suppliers do not have the strongest incentive to monitor and claim review of possible breaches. ${ }^{*} 76$ In addition, the burden of proof may be unreasonably heavy for competitors. ${ }^{*} 77$ Therefore, instead of subjecting the cases of unlawful contract modification to supplier review, an additional or alternative system of outside review in the way of disciplinary, administrative, or criminal sanctions could be considered by national legislators. That may appear to be a more effective way of enforcing the rules on public contract modification. ${ }^{*} 78$

Such alternative or additional outside review options could have the specific benefit of discovering and imposing sanctions for breaches of public contract modification rules that could go undetected or unchallenged under the peer-review system. Detection and enforcement through an external national system of sanctions could be worth considering especially if the external review body will be able to practise a proactive approach to detecting and expeditiously sanctioning breaches. ${ }^{*} 9$ While the reactive review procedures currently practised in accordance with the remedies directives remain available to persons with a direct interest and incentive to initiate review proceedings, persons with no standing for the purpose of review proceedings could be able to refer breaches to such competent authority. The alternative means of involvement would guarantee 'sound procurement procedures' as indicated in the recitals to the new directives. ${ }^{* 80}$ Accordingly, the outside review can better serve the need of effective enforcement of the new rules on contract modification.

\section{Conclusions}

Enforcement of the rules on public contract modification can lead to ineffectiveness of the unlawfully modified contract or a part of it. In public procurement cases, parties must be given standing before the court or the review body at least if they can show sufficient interest in the concerned contract and the presence

\footnotetext{
S. Treumer 2012, p. 153.

74 Article 72 (1) of the Public Procurement Directive; Article 89 (1) of the Utilities Directive; Article 43 (1) of the Concessions Directive.

75 R. Williams. Anti-corruption measures in the EU as they affect public procurement. - Public Procurement Law Review 4, 2014, p. NA99.

76 Zhang 2007, p. 329.

77 Ibid., p. 334.

78 Ibid., pp. 341-343.

79 Zhang 2007, p. 345. Arrowsmith, Linarelli, Wallace. Regulating Public Procurement: National and International Perspectives. Kluwer Law International 2000, p. 825.

80 Recital 122 of the Public Procurement Directive; Recital 128 of the Utilities Directive.
} 
of prejudice caused by the breach. In matters of contract modification, any potential bidder should satisfy these requirements. Only when it is 'plainly obvious' that they have no potential for competing for the contract should the person be found to have no standing. As a rule, parties protecting general or indirect interests should not have standing for the purpose of using public procurement remedies.

Wider legal implications of contract ineffectiveness under national jurisdictions can be controversial, particularly with regard to financial rights of contractors (suppliers) in relation to contracting authorities, following ineffectiveness. Moreover, the new directives can be interpreted to allow exclusion from future procurements of contractors (suppliers) who have been parties to agreements providing unlawful modification. Thereby, in some jurisdictions, contractors become de facto duty-holders bearing actual liability for upholding the public contract modification rules, while in others they would suffer a much lesser burden.

A genuine opportunity to effectively challenge unlawful contract modifications by means of peer review requires third-party access to information about the contract performance, incl. modifications. The lack of clear rules on access to information on public contracts can discourage effective review practices. Either as alternatives to contract ineffectiveness or as additional review options, sanctions enforceable through external (administrative) review could benefit the purpose of upholding the rules on contract modification.

In order to provide a uniform system of remedies for interested third parties, to level the regime of enforcing public contract modification rules, and to allow for efficient enforcement of EU public procurement law, the current system of remedies in public procurement might benefit from review. 